\title{
ВИЗНАЧЕННЯ ПРИНЦИПІВ І ПІДХОДІВ ДО ОЦІНКИ ЯКОСТІ ПРОДУКЦії ПРОМИСЛОВОГО ВИРОБНИЦТВА
}

() В. І. Хімич, Мукачівський державний університет, Мукачево, Україна, А. С. Зенкін, д.т.н., професор,

Г. І. Хімічева, д.т.н., професор, Київський національний університет технологій та дизайну, Київ, Україна

Проанализированы принципы, методы и подходы к оценке качества и конкурентоспособности продукции обувного производства и определены механизмы и инструменты их проведения.

Principles, methods and approaches to assess the quality and competitiveness of shoe production and the mechanisms and tools of their conduct.

\section{Постановка проблеми}

Членство України в СОТ й пов'язані з цим корінні зміни господарських відносин ставлять вітчизняні взуттєві підприємства перед необхідністю працювати за законами й вимогами ринку, пристосовуючи всі сторони своєї діяльності до мінливої ринкової ситуації і швидкоплинних вимог споживача, змагаючись при цьому з конкурентами.

Слід зазначити, що споживчий ринок взуття відіграє важливу роль у забезпеченні населення взуттям. Однак тенденції, що склалися сьогодні в розвитку національної галузі взуттєвого виробництва свідчать не на їі користь. Це пов'язано з тим, що в останні роки спостерігається суттєве зменшення обсягів випуску вітчизняної продукції, переважання на ринку продукції іноземного та нелегального походження, відчуваються проблеми якості самої взуттєвої продукції. Тому розроблення принципів, методів до оцінювання якості взуття, побудованих на сучасних підходах і враховуючих вимоги споживача $є$ актуальним завданням.

\section{Мета роботи}

Визначення принципів і методів оцінювання якості взуття 3 урахуванням сучасних підходів i швидкоплинних вимог споживача.

\section{Результати проведених досліджень}

Згідно ДСтУ 2925 [1] оцінка якості взуття - це сукупність операцій по вибору номенклатури показників, визначенню їх дійсних значень та їх співставлення з базовими показниками. При цьому результатом оцінки є обґрунтований висновок про якість кожного зразка взуття або всієї партії за споживчими вимогами.

Проведені авторами дослідження, результати яких викладено в [2, 3] доводять, що перед виробниками взуття постали 
проблеми відповідності вітчизняного взуття європейським директивам, регламентуючих вимоги споживача і держави до безпеки, комфортності якості.

В світовій практиці виживання будь-якої фірми, її стійке положення на споживчому ринку визначаються рівнем її конкурентоспроможності. Остання безпосередньо пов'язана з двома такими показниками, як рівень ціни і рівень якості продукції. При цьому другий показник поступово і впевнено виходить на перше місце.

Одним із перспективних шляхів відродження вітчизняного взуттєвого виробництва $є$ впровадження на підприємствах ідеології TQM і систем управління якістю побудованих на вимогах міжнародних стандартів [3-5]. Такий підхід до модернізації виробництв передбачає поетапний моніторинг як перебігу технологічних процесів так і самої продукції. Останню доцільно оцінювати за нормованими показниками якості.

Проведений аналіз показників якості продукції взуттєвого виробництва показав, що їх доцільно розбити на 4 групи за такими ознаками: призначення взуття; експлуатаційні властивості взуття; виробничо-технологічні аспекти та економічні аспекти.

До першої групи показників, що визначають призначення взуття в ході досліджень, було віднесено показники, що характеризують вид матеріалу верху і низу взуття, умови його експлуатації. Відповідність взуття його призначенню, як доводять опи- тування споживачів, є однією 3 важливих ознак його якості.

Друга група показників $€$ достатньо різноманітною і великою, тому її було запропоновано поділити ще на чотири підгрупи, що характеризують такі споживчі властивості взуття як його надійність, ергономічність, гігієнічність та естетичність. В свою чергу кожна із підгруп має свої показники. Наприклад, надійність взуття визначається показниками, що відображають зносостійкість його складових частин, збереження форми, довговічність, ремонтопридатність, сортність. Для сучасних умов життя і праці велике значення мають ергономічні та гігієнічні показники. Перші визначають жорсткість, еластичність, масу, а другі його теплозахисні і вологостійкі властивості. Крім того останнім часом все більше уваги споживачі приділяють естетичним показникам (силует, забарвленість, стилістика та ін.).

В ході досліджень встановлено, що зі всіх вищеперерахованих показників найбільш суттєвими є показники надійності, які узагальнюють різні фізико-механічні властивості взуття. Це пов'язане з тим, що навіть саме модне, саме потрібне взуття не буде придбане, якщо покупець сумнівається, чи не «розвалиться» воно наступного дня.

Надійність і довговічність поняття тісно пов'язані, однак, аж ніяк нетотожні. Під надійністю слід розуміти повне, безвідмовне, без ремонту збереження властивостей взуття на протязі всього його періоду екс- 
плуатації, який регламентовано нормативним документом. Довговічність характеризує тривале збереження (до повного зносу) властивостей взуття при його періодичному ремонті.

Кількісне (чисельне) оцінювання надійності взуття, регламентоване вимогами національних стандартів, і виражається, як правило, в гарантійному терміні носіння, в межах якого воно відповідає задекларованій в документі якості.

Відповідність взуття гігієнічним показникам одна 3 об'єктивних ознак, яка визначає його якість і приваблює потенційного покупця. Згідно діючих нормативів гігієнічні вимоги до взуття зводяться в основному до відповідності останнього формі і розмірам стопи, крім того воно не повинне перешкоджати зміні габаритних розмірів стопи під час ходьби, здавлювати стопу, сприяти утворенню потертості.

Модним, красивим, комфортним і елегантним взуття може бути тільки в тому випадку, коли модельєр-конструктор при розробці моделі дотримувався законів естетики та нормативних вимог до деталей та матеріалів взуття. Перш за все, це стосується закону пропорційності (при діленні берців і союзок на більш дрібні деталі). Часто для поліпшення композиційного рішення застосовуються прикраси у вигляді бантів, пряжок, декоративних ґудзиків, перфорації, а також тонування, вишивка, тиснення і т. п., але нажаль вони, як правило, знижують комфортність майбутнього взуття.
Слід зазначити, що для естетичного сприйняття велике значення має колір взуття, який формує модні тенденції і навіть визначає його функціональне призначення.

До виробничо-технологічних показників якості взуття відносяться: конструкція взуття, форма колодки, метод формування заготовки на колодці, метод кріплення низу, якість матеріалів, комплектуючих та сировини дотримання технологічних норм і приписів. Однак для їх виконання і підтримки потрібно мати сучасні, високоефективні технології, які, наприклад, забезпечували би мінімальну кількість операцій і технологічних стиків; мали змогу виконувати цілу низку операцій і працювали б на якісній сировині.

Економічні показники включають в себе відпускні та роздрібні ціни, собівартість, втрати від браку та рекламації. Цей зв'язок безпосередньо прослідковується при визначенні розміру економічної ефективності від досягнутого рівня якості взуття. Так, чим вище сортність взуття, тим якісніший його асортимент, тим вище його ціна. Такий підхід до визначення рівня якості дозволяє проводити його комплексну оцінку.

В загальному випадку рівень якості розраховується за формулою:

$$
\mathrm{K}_{\mathrm{i}}=\frac{\mathrm{Q}_{\mathrm{i}}}{\mathrm{Q}_{\mathrm{o}}},
$$

де $\mathrm{K}_{\mathrm{i}}$ - показник рівня якості взуттєвого виробу, що оцінюється; $Q_{i}-$ характеристика 
рівня якості взуттєвого виробу, що оцінюється; $Q_{0}-$ характеристика рівня якості еталону, за яким проводиться оцінювання.

Якщо $\mathrm{K}_{\mathrm{i}}=1$, то продукція відповідає якості еталону, у випадку коли $\mathrm{K}_{\mathrm{i}}<1$, вважається що виріб має якість нижче необхідного нормованого рівня.

При проведенні комплексної оцінки рівня якості взуття всі показники, що використовуються в процесі оцінювання приводяться до однакового вигляду. Такий підхід дозволяє проводити порівняння їх між собою:

$$
\mathrm{K}_{\mathrm{i}}=\frac{\sum^{\mathrm{n}} \mathrm{b}_{\mathrm{i}} \mathrm{P}_{\mathrm{i}}}{\sum^{\mathrm{n}} \mathrm{b}_{0} \mathrm{P}_{0}},
$$

де $\mathrm{b}_{\mathrm{i}}$ i $\mathrm{b}_{0}$ - оцінка в балах показників якості виробу, що оцінюється та еталону за яким проводиться оцінювання; $\mathrm{P}_{\mathrm{i}}$ i $\mathrm{P}_{0}$ - коефіцієнт значимості кожного показника виробу, що оцінюється та еталону $\left(\mathrm{P}_{\mathrm{i}}=\mathrm{P}_{0}\right)$; $\mathrm{n}$ - кількість показників якості, які приймають участь в процедурі оцінювання.

За таких умов комплексна оцінка рівня якості взуттєвого виробу дорівнює:

$$
\mathrm{K}_{\mathrm{i}}=\sum \mathrm{m}_{\mathrm{i}} \mathrm{Q}_{\mathrm{i}}
$$

де

$$
Q_{i}=\frac{P_{i}}{P_{\text {eт }}},
$$

Qi - відносний показник якості взуттєвої продукції; $\mathrm{P}_{\mathrm{i}}$ показник якості взуттєвої продукції, що оцінюється; $\mathrm{P}_{\mathrm{eт}}$ - базовий еталонний показник якості; $\mathrm{m}_{\mathrm{i}}$ - коефіцієнт вагомості і-го показника якості.

Таким чином, використання наведених процедур дозволяє оцінити якість взуття та обґрунтувати його техніко-економічні показники, тобто визначити його конкурентоспроможність на споживчому ринку.

\section{Висновки}

Проаналізовано принципи, методи та підходи до оцінки якості та конкурентоспроможності продукції взуттєвого виробництва та визначено механізми і інструменти їх проведення. Показано, що споживчий ринок взуття формується під впливом швидкоплинних вимог споживача і є сегментарним.

1. ДСту 2925-94. Якість продукції. Оцінка якості. Терміни та визначення. Введ. 01.01 .96 р. - К. : Держстандарт України, 1994. - 28 с. 2. Хімічева Г. І. Розробка оцінки конкурентоспроможності продукції взуттєвого виробництва / Г. І. Хімічева, Ю. П. Чайка, В. І. Хімич // Вісник КНУТД. - 2009. № 3(47). - С. 165-169. 3. Хімич В. І. Дослідження суб'єктивних показників комфортності молодіжного взуття / В.І.Хімич, В. П. Либа, В. М. Січка // Вісник Технологічного університету Поділля. Технічні науки. - 2002. - № 5, част. 1. - С. 57-61. 4. Хімічева Г. І. Економічні аспекти впровадження інтегрованих систем управління / Г.І.Хімічева // Збірник наукових праць Вісник КНУТД. - 2005. - № 1(21). - С. 54-59. 5. Хімічева Г. І. Методологічні аспекти алгоритму побудови і впровадження інтегрованих систем управління / Г. І. Хімічева // Збірник наукових праць Вісник КНУТД. - 2005. 
№ (22). - С. 25-32. 6. Хімічева Г. І. Кваліметрична оцінка нормативних складових процесно-оріентованої системи управління / Г. І. Хімічева, Н. В. Білей-Рубан, В. І. Хімич, О. А. Деміденко // Вісник КНУТД. — 2007. — № 3. C. 29-35.

1. DSTU 2925-94. Yakist produktsii. Otsinka yakosti. Terminy ta vyznachennia. Vved. 01.01 .96 r. - K. : Derzhstandart Ukrainy, 1994. - 28 s. 2. Khimicheva H. I. Rozrobka otsinky konkurentospromozhnosti produktsii vzuttievoho vyrobnytstva / H. I. Khimicheva, lu. P. Chaika, V. I. Khimych // Visnyk KNUTD. 2009. - № 3(47). - S. 165-169. 3. Khimych V. I. Doslidzhennia sub'iektyvnykh pokaznykiv komfortnosti molodizhnoho vzuttia / V. I. Khimych, V. P. Lyba, V. M. Sichka // Visnyk Tekhnolohichnoho universytetu Podillia. Tekhnichni nauky. - 2002. - № 5, chast. 1. - S. 57-61. 4. Khimicheva H. I. Ekonomichni aspekty vprovadzhennia intehrovanykh system upravlinnia / H. I. Khimicheva // Zbirnyk naukovykh prats Visnyk KNUTD. - 2005. - № 1(21). - S. 54-59. 5. Khimicheva H. I. Metodolohichni aspekty alhorytmu pobudovy i vprovadzhenniaintehrovanykh system upravlinnia / H. I. Khimicheva // Zbirnyk naukovykh prats Visnyk KNUTD. - 2005. - № 2(22). - S. 25-32. 6. Khimicheva H. I. Kvalimetrychna otsinka normatyvnykh skladovykh protsesno-orientovanoi systemy upravlinnia / H. I. Khimicheva, N. V. Bilei-Ruban, V. I. Khimych, O. A. Demidenko // Visnyk KNUTD. - 2007. - № 3. - S. 29-35.

Рецензент - П. О. Киричок, д.т.н., професор, НТУУ «КПІ»

Надійшла до редакції 18.06.13 